medical causes in this country is associated with HIV infection. The contribution of HIV to the smaller increase in the number of deaths due to external HIV related causes is more tenuous and requires further investigation. This could include testing for HIV in people who die of or receive medical care for these conditions. Accurate diagnosis and more complete reporting are required if the full extent of the HIV epidemic is to be identified.

I thank my colleague Tim Devis, statistician, for his help in extracting mortality data.

1 Buehler J, Berkelman R, Devine O, Chevarley F. Impact of the human immunodeficiency virus epidemic on mortality trends in young men, United States. Am f Public Health 1990;80:1080-6.

2 Centers for Disease Control. Increase in pneumonia mortality among young adults and the HIV epidemic. $M M W R$ 1988;37:593-6.

3 Marzuk PM, Tierney H, Tardiff K, Gross EM, Morgan EB, Hsu M-A, et al. Increased risk of suicide in persons with AIDS. FAMA 1988;259:1333-7.

4 Darby SC, Rizza CR, Doll R, Spooner RJD, Stratton IM, Thakrar B. Incidence of AIDS and excess mortality associated with HIV in haemophiliacs in the United Kingdom: report on behalf of the directors of haemophilia centres in the United Kingdom. BMF 1989;298:1046-8.

5 McCormick A. Trends in mortality statistics in England and Wales with particular reference to AIDS from 1984 to April 1987. BMF 1988;296: 1289-92.

(Accepted 18 April 1991)

\title{
HIV surveillance: the value of audit
}

\section{Matthew Hickman, John Aldous, John Porter, Linda Durman}

Department of Public

Health, Riverside Health

Authority, London

SW6 4UL

Matthew Hickman, BSC,

district HIV information

officer

John Aldous, MRCGP,

registrar in public health

medicine

Linda Durman, MFPHM,

director of public health

Public Health Laboratory

Service Communicable

Disease Surveillance

Centre, London NW9 5EQ

John Porter, MFPHM

consultant in public health

medicine

Correspondence to: $\mathrm{Mr}$

Hickman.

BMF 1991:302:1376-7
Surveillance of the HIV epidemic in England and Wales relies on two national voluntary reporting systems run by the Public Health Laboratory Service Communicable Disease Surveillance Centre: one for cases of AIDS, the other for positive results of HIV antibody tests. The Communicable Disease Surveillance Centre collates this information and identifies duplicate reports to form anonymised national databases of cases of AIDS and patients positive for HIV. In future this form of surveillance will be supplemented by the unlinked anonymous testing programme.

Although several studies have shown underreporting of cases of AIDS, ${ }^{2-4}$ little is known of the effectiveness of the national surveillance of results of tests for HIV antibody. We evaluated the reporting of these results from Riverside Health Authority.

\section{Subjects, methods, and results}

We identified 14 sources of information on people infected with HIV in the district (table). From July to September 1989 we collected data from these sources, entered them on to a computerised database, and cross checked them for duplicate reporting. We reviewed case notes if there were insufficient data to identify duplicate reports or to confirm HIV infection if the result of an HIV antibody test had not been recorded. If case notes were unobtainable or contained no record of HIV infection we removed that record from the database.

We compared the number of subjects with a positive result of an HIV antibody test performed in the district with the number attributed to the district by the national surveillance system up to July 1989.
The study identified 2867 people with HIV infection (table); 2808 had a record of a positive result of an HIV antibody test performed in the district. The Communicable Disease Surveillance Centre had records of 1861 people with a positive result reported from Riverside. Therefore 947 either had not been reported or had been first reported from another district health authority.

In Riverside one laboratory did not report positive test results to the Communicable Disease Surveillance Centre, and one genitourinary clinic used a reference laboratory for primary testing for HIV antibody which also did not report its positive results. Together these sources were responsible for 621 of the positive results identified by this study. We reported test results from these two sources to the Communicable Disease Surveillance Centre, which accepted 617 as being reported for the first time and retrospectively incorporated them into the national figures. This increased the number of people with a positive test result attributed to Riverside by $33 \%$ and the total for England and Wales by $6 \%$. The remaining positive results were checked further by the Communicable Disease Surveillance Centre to identify any that had not been reported previously.

\section{Comment}

Underreporting of positive results of HIV antibody tests reduces the usefulness of the national surveillance system as a means of monitoring changes in the HIV epidemic and of planning effective prevention strategies. This study showed that between $22 \%$ and $34 \%$ of the positive results of tests performed in Riverside had not been reported to the Communicable Disease Surveillance Centre. Although this scale of underreporting may be peculiar to Riverside, we recommend that all health authorities should audit their reporting of positive results. An essential first step is to ensure that each laboratory undertaking primary testing for HIV antibody is reporting to the national surveillance system.

Furthermore, it is important that laboratories

Sources of data used in Riverside Health Authority

\begin{tabular}{|c|c|c|c|}
\hline & No of data sources & Type of data source & No of records \\
\hline Genitourinary clinic & $\begin{array}{l}2 \\
1 \\
1 \\
1\end{array}$ & $\begin{array}{l}\text { Computerised database of patients with HIV infection } \\
\text { File register of patients with HIV infection } \\
\text { List of patients with HIV infection in } 1987 \\
\text { List of cases of AIDS reported to Communicable Disease Surveillance Centre }\end{array}$ & $\begin{array}{r}2300 \\
457 \\
193 \\
226\end{array}$ \\
\hline Microbiology laboratory & $\begin{array}{l}1 \\
2\end{array}$ & $\begin{array}{l}\text { Computerised database of tests for HIV antibody } \\
\text { Register of tests for HIV antibody }\end{array}$ & $\begin{array}{r}1923 \\
664\end{array}$ \\
\hline Hospital inpatients & $\begin{array}{l}1 \\
1 \\
1 \\
1\end{array}$ & $\begin{array}{l}\text { Patient administration system } \\
\text { Hospital ward book } \\
\text { List of inpatients with HIV infection } \\
\text { List of cases of AIDS reported to Communicable Disease Surveillance Centre }\end{array}$ & $\begin{array}{l}215 \\
156 \\
160 \\
119\end{array}$ \\
\hline Other & $\begin{array}{l}1 \\
1\end{array}$ & $\begin{array}{l}\text { List of patients with HIV infection in } 1985 \\
\text { Computerised database of death certificates }\end{array}$ & $\begin{array}{r}32 \\
288\end{array}$ \\
\hline $\begin{array}{l}\text { No of records collected } \\
\text { No of duplicates } \\
\text { No of people with HIV in }\end{array}$ & & & $\begin{array}{l}6733 \\
3866 \\
2867\end{array}$ \\
\hline
\end{tabular}

I


include data on exposure category, age, sex, and postcode in their reports of positive test results. In Riverside a comprehensive request form for the test is being introduced to ensure that each laboratory can report the relevant epidemiological data.

We thank the following clinicians and microbiologists for their cooperation and support during the study: $\mathrm{Dr} \mathrm{J} \mathrm{C}$ Coleman, Dr B A Evans, Dr B Gazzard, Professor A Guz, Dr D A Hawkins, Dr L Howard, Dr A G Lawrence, Dr K A
McClean, Dr I M Murray-Lyon, Dr P L Samarasinghe, and Dr D C Shanson.

1 Gill ON, Adler MW, Day NE. Monitoring the prevalence of HIV: foundations for a programme of unlinked anonymous testing in England and Wales. $B M \mathcal{J}$ 1989:299:1295-8.

2 Duff $C$, Hutchby JP. Surveillance of AIDS cases: How acceptable are the figures? BMJ 1988;297:965.

3 Bobby JJ, Spencer PD, Wyatt JC, Farmer RDT. AIDS deaths in the UKHow complete are the figures? Public Health 1988;102:519-24.

$4 \mathrm{McCormick} A$. Estimating the size of the HIV epidemic by using mortality data. Philos Trans R Soc Lond (Biol) 1989;325:163-73.

(Accepted 5 March 1991)

\section{Characteristics of general practitioners who did not claim the first postgraduate education allowance}

\section{T S Murray, G S Dyker, L M Campbell}

\section{West of Scotland Committee for Postgraduate Medical Education, University of Glasgow, Glasgow G12 8QQ \\ T S Murray, FRCGP, adviser in general practice G S Dyker, FRCGP, deputy adviser in general practice L M Campbell, MRCGP, assistant adviser in assessment \\ Correspondence to: Dr Murray.}

BMF 1991;302:1377
Attendance by general practitioners at postgraduate meetings fell when such attendances ceased to be obligatory for seniority payments, ${ }^{1}$ and studies of nonattenders have not shown definite trends. ${ }^{1-3}$ The 1990 contract includes a postgraduate education allowance, which is paid as part of the statement of fees and allowances ${ }^{4}$; a general practitioner needed to have completed 10 sessions of accredited education between 1 April 1989 and 30 September 1990 to obtain the first allowance.

The West of Scotland Committee for Postgraduate Medical Education has set up a computerised database that records all attendances by doctors at accredited meetings both within and outwith the region (T S Murray et al, unpublished report). The region comprises six health boards and includes 1802 general practitioners serving $2 \cdot 8$ million patients. We studied the characteristics of the general practitioners in the region who were not eligible to claim for the education allowance.

\section{Methods and results}

A printout was obtained from the database on 31 December 1990 of all general practitioners in the west of Scotland who had attended fewer than 10 sessions of accredited education. The latest editions of the Medical Register, the General Medical Council list, and the health board lists were used to determine the data of qualification, membership of the Royal College of General Practitioners, and the structure of each doctor's practice.

A total of 102 doctors had attended insufficient sessions to claim the allowance; all of them had attended two or fewer sessions. Their distribution among the six health boards is shown in the table. Of

Numbers (percentages) of general practitioners not eligible for postgraduate education allowance in west of Scotland by health board

\begin{tabular}{lcr}
\hline Health boards & Total & $\begin{array}{r}\text { Not eligible } \\
\text { for allowance }\end{array}$ \\
\hline Greater Glasgow & 653 & $42(6 \cdot 4)$ \\
Lanarkshire & 300 & $16(5 \cdot 3)$ \\
Argyll and Clyde & 307 & $17(5 \cdot 5)$ \\
Ayrshire and Arran & 252 & $14(5 \cdot 6)$ \\
Dumfries and Galloway & 104 & $4(3 \cdot 8)$ \\
Forth Valley & 186 & $9(4 \cdot 8)$ \\
\hline Total & 1802 & $102(5 \cdot 7)$ \\
\hline
\end{tabular}

the 102,18 were women and 14 were members of the royal college. Fifty three were in a single handed or a two person practice, and 38 had been qualified for over 30 years. The distance from an educational centre did not seem to affect attendance at accredited sessions as only 20 of the general practitioners were based more than $16 \mathrm{~km}$ from one. The policy of the practice seemed to be important, however, as 48 doctors came from 38 practices.

\section{Comment}

The general practitioners most in need of postgraduate education took the least part in it: doctors in small practices, for example, need to share experiences with their peers. Those ineligible for the allowance had obviously consciously decided not to attend accredited sessions as they had all accrued a maximum of only two.

General practitioners were initially concerned that the time spent away from the practice, the course fees, and the lack of reimbursement of travel and subsistence costs would make postgraduate education not cost effective under the new contract. The fact that almost $95 \%$ of doctors fulfilled the requirements suggests, however, that the postgraduate education allowance is one of the successes of the 1990 contract. Only a few general practitioners were based far from a centre, and the fears that attendance would fall with the removal of the travel and subsistence budget have not been justified. Interestingly, Greater Glasgow has the highest concentration of general practitioners and the highest proportion of doctors who did not claim the allowance.

The length of time since qualification was important. Those who had been qualified for some time might have been overwhelmed by the changes in the contract and not had sufficient time to follow their educational requirements. Some might have been preparing for retirement and others might have taken a 24 hour retirement in which the money that they could earn thereafter was restricted.

Our study has shown some interesting characteristics of general practitioners who did not claim the postgraduate education allowance. The high uptake of this allowance is encouraging, but work is required to ensure that the quality of the material presented is worth while and relevant to general practitioners' day to day practice.

\footnotetext{
1 Wood J, Byrne PS. Section 63 activities. London: Royal College of General Practitioners, 1980. (Occasional Paper 11.)

2 Reedy BLEC. General practitioners and postgraduate education in the Northerm region. London: Royal College of General Practitioners, 1979. (Occasional Paper 9.)

3 Branthwaite A, Ross A, Henshaw A, Davie C. Continuing education for general practitioners. London: Royal College of General Practitioners, 1988. (Occasional Paper 38.)

4 Department of Health and Welsh Office. General practice and the National Health Service. A new contract. London: Department of Health, 1989. 